\title{
ニュージーランドカオリンから生成した針状ムライトの高温特性
}

勝木宏昭・川原昭彦・一ノ瀬弘道 - 古田祥知子 ·吉田秀治

（佐賀県窯業試験場ファインセラミックス部, 佐賀県西松浦郡有田町中部 3100-5)

\section{High-Temperature Properties of Needle-Like Mullite Obtained from New Zealand Kaolin}

Hiroaki KATSUKI, Akihiko KAWAHARA, Hiromichi ICHINOSE, Sachiko FURUTA and Shuji YOSHIDA

$\left(\begin{array}{l}\text { Ceramics Industrial Research Institute of Saga Prefectural Government, } \\ 3100-5 \text {, Chubu Arita-machi, Nishimatsuura-gun, Saga } 844\end{array}\right)$

Needle-like mullite was prepared by leaching out the silica glass from New Zealand kaolin fired at $1550^{\circ}$ to $1700^{\circ} \mathrm{C}$. Hightemperature properties of the needle-like mullite, such as thermal expansion and thermal shock were examined. Needle-like

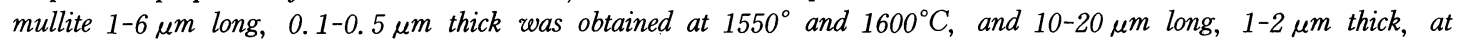
$1650^{\circ}$ and $1700^{\circ} \mathrm{C}$. The specific surface area of these crystals grown at $1550^{\circ}$ and $1650^{\circ} \mathrm{C}$ were 8.2 and $4.1 \mathrm{~m}^{2} / \mathrm{g}$ respectively, and did not decrease with reheating in the temperature range from $1000^{\circ}$ to $1650^{\circ} \mathrm{C}$ for $20-30 \mathrm{~h}$. The axial thermal expansion coefficients of crystals at $25^{\circ}-800^{\circ} \mathrm{C}$ were $\alpha_{a}=2.2, \alpha_{b}=3.9$ and $\alpha_{c}=4.5 \times 10^{-6} /{ }^{\circ} \mathrm{C}$. No evidences of fracture and crack were detected on quenching needle-like mullite crystals from $1150^{\circ} \mathrm{C}$ to $0^{\circ} \mathrm{C}$.

[Received April 24, 1989; Accepted August 22, 1989]

Key-words : Needle-like mullite, Thermal shock, Single crystal, Thermal expansion coefficient, New Zealand kaolin

\section{1. 緒 言}

ニュージーランドカオリンを $1650^{\circ} \mathrm{C} て ゙ ~ 2$ 時間焼成し たのち，フッ化水素酸 (以下 $\mathrm{HF}$ と省す) でガラス相 を溶出すると, 長さ $10 \sim 20 \mu \mathrm{m}$, 太さ $1 \mu \mathrm{m}$ の針状ムラ イトが密に交錯して得られることを先に著者らは明らか にした1).この結晶は $c$ 軸方向に成長し, アスペクト比 が 10 15 の単結晶であり, また $\mathrm{Al}_{2} \mathrm{O}_{3}$ と $\mathrm{SiO}_{2}$ のモル 比が約 1.5 であるので, 高温構造用セラミックスの強化 材としての利用が興味深い。しかしながら，天然粘土鉱 物の焼成により生成する針状ムライト ${ }^{2) ~}$ 出の諸特性につ いては, まだ不明の点が多い. したがって本研究では, ニュージーランドカオリンを $1550^{\circ} \sim 1650^{\circ} \mathrm{C}$ で焼成した のち, HF によるガラス相の溶出処理により得られた針 状ムライトの高温特性について調べた.

\section{2. 実験方法}

\section{1 針状ムライトの生成}

まず前報1) と同様にして厚さ約 $0.25 \mathrm{~mm}$ のニュージー ランドカオリンのシートを押し出し成形により作製し た。乾燥後, $1550^{\circ}, 1600^{\circ}, 1650^{\circ}, 1700^{\circ} \mathrm{C} て ゙ 2$ 時間焼成 した。ガラス相を十分に溶出させるために，焼成体を 9.2 18.4\% HF $\left(40^{\circ} \mathrm{C}\right)$ が入ったポリエチレン容器に 入れて密封し， $42 \sim 48$ 時間処理した. 焼成シートの表 面よりガラス相の溶出が進むと, HF 溶液が白濁し針状 ムライトが容器の底に沈殿する．沈殿したムライトを蒸 溜水で洗浄 $(\mathrm{pH}=6 \sim 7)$ して回収した. 針状ムライト の結晶を走查型電子顕微鏡 (SEM; 日本電子製,
JXA-840 型), 透過型電子顕微鏡 (TEM; 日本電子製, 100 U型) で観察し, また化学組成は蛍光 X線（理学電 機製，3070型）で調べた. 更に針状ムライトの比表面 積を BET 法比表面積測定装置（湯浅アイオニクス製, オートソーブ1) で測定するとともに, 真密度をピク, メーターにより $20^{\circ} \mathrm{C}$ の水中で測定した.

\section{2 針状ムライトの高温特性}

針状ムライトの高温特性を明らかにするために, まず $1550^{\circ}, 1650^{\circ} \mathrm{C}$ で生成した結晶を $1000^{\circ} \sim 1720^{\circ} \mathrm{C}$ で 4 一 30 時間再焼成し, 形態及び比表面積の変化を調べた. つぎに針状ムライトの熱膨張挙動を調べるために, 高温 X線回折（マックサイエンス製，MAP 3 型，40 KV-30 $\mathrm{mA}, \mathrm{Cu}$ 管球) により $25^{\circ} \sim 800^{\circ} \mathrm{C}$ でムライトの $(130)$, （201）及び（230）線を測定し, 各温度における格子定 数を算出して各結晶軸 $(a, b, c$ 軸) の熱膨張率を求め た.なお針状ムライトに Pt 粉末を添加して回折角の補 正を行い, 格子定数の精密化は格子定数を $\frac{1}{2}\left(\frac{\cos ^{2} \theta}{\sin \theta}+\frac{\cos ^{2} \theta}{\theta}\right)$ の関数としてプロットし最小二乗 法により行った. 更に針状ムライトの熱衝撃性を調べる ために, $1150^{\circ} \mathrm{C} て ゙ 2$ 時間加熱後水中へ急冷し, 形態, 結晶構造の変化を SEM, TEM 及びX線回折により検討 した.

\section{3. 結果と考察}

\section{1 各焼成温度で焼成した針状ムライトの性状}

まず表 1 に $1550^{\circ} \sim 1700^{\circ} \mathrm{C}$ で生成した針状ムライトの 結晶サイズ, 真密度, 化学組成及び比表面積の結果を示 
Table 1. Some properties of needle-like mullite obtained at $1550^{\circ}-1700^{\circ} \mathrm{C}$ for $2 \mathrm{~h}$.

\begin{tabular}{cccccc}
\hline $\begin{array}{l}\text { Growth } \\
\text { temp. }\left({ }^{\circ} \mathrm{C}\right)\end{array}$ & $\begin{array}{l}\mathrm{Av} . \\
\text { length }(\mu \mathrm{m})\end{array}$ & $\begin{array}{l}\mathrm{Av} \\
\text { thickness }(\mu \mathrm{m})\end{array}$ & $\begin{array}{l}\mathrm{Al}_{2} \mathrm{O}_{3} / \mathrm{SiO}_{2} \\
(\mathrm{molar} \mathrm{ratio})\end{array}$ & $\begin{array}{l}\text { Density } \\
\left(\mathrm{g} / \mathrm{cm}^{3}\right)\end{array}$ & $\begin{array}{l}\text { Specific surface } \\
\text { area }\left(\mathrm{m}^{2} / \mathrm{g}\right)\end{array}$ \\
\hline 1550 & $1-3$ & $0.1-0.4$ & 1.48 & 3.14 & 8.2 \\
1600 & $3-6$ & $0.2-0.5$ & 1.47 & 3.16 & 6.7 \\
1650 & $10-20$ & $0.8-1.1$ & 1.48 & 3.15 & 4.1 \\
1700 & $10-20$ & $0.7-1.3$ & 1.48 & 3.14 & 3.9 \\
\hline
\end{tabular}
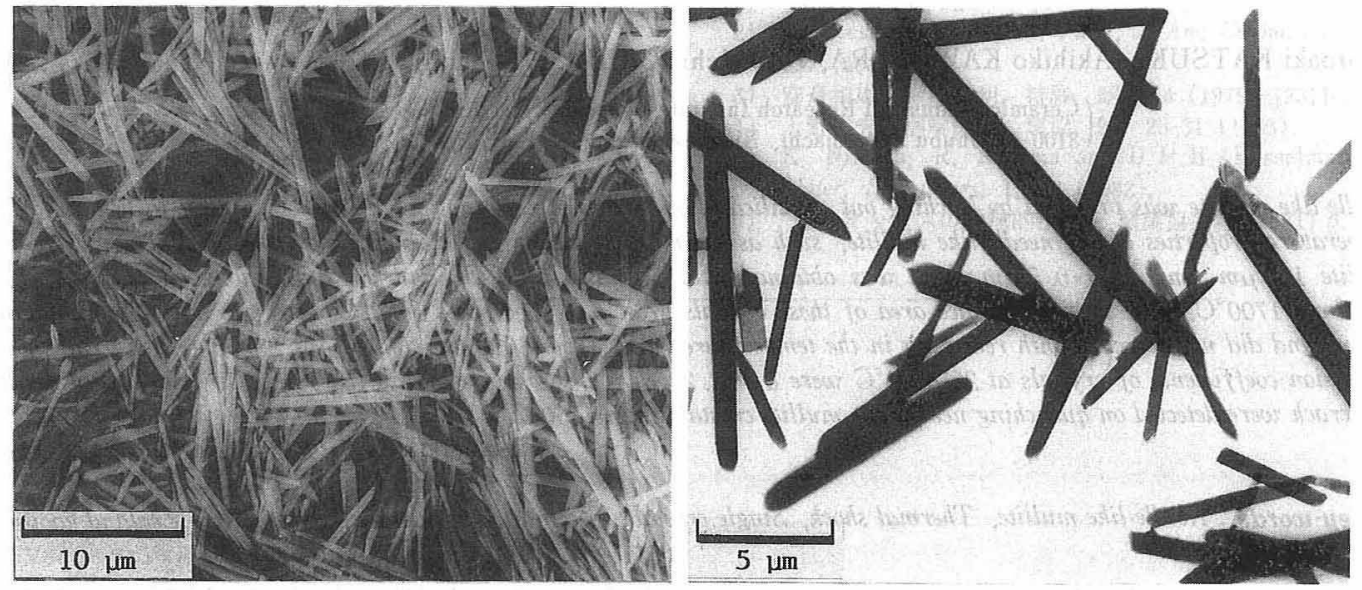

Fig. 1. SEM and TEM micrographs of needlde-like mullite obtained at $1650^{\circ} \mathrm{C}$ for $2 \mathrm{~h}$.

す. $1550^{\circ} \sim 1600^{\circ} \mathrm{C}$ では結晶は微細であり，平均長さは $5 \mu \mathrm{m}$ 以下のものが多く, 比表面積は $6.7 \sim 8.2 \mathrm{~m}^{2} / \mathrm{g}$ で あった. $1650^{\circ} \sim 1700^{\circ} \mathrm{C}$ では平均長さ $10 \sim 20 \mu \mathrm{m}$, 平均 太さ $0.7 〜 1.2 \mu \mathrm{m}$ と結晶サイズが大きくなるので，比 表面積は 3.9 - $4.1 \mathrm{~m}^{2} / \mathrm{g}$ と低下した，またいずれの温度 で生成した結晶も単結晶で, 結晶の伸長方向は (001) であった. また, $\mathrm{Al}_{2} \mathrm{O}_{3}$ と $\mathrm{SiO}_{2}$ (モル比) は約 1.48 , 真密度は $3.14 \sim 3.16 \mathrm{~g} / \mathrm{cm}^{3}$ であり，各温度で生成した 針状ムライトに相違は認められなかった。 $1650^{\circ}$ 〜 $1700^{\circ} \mathrm{C}$ で生成した針状ムライトは図 1 のようにアスペ クト比が 10 20で, 均一な形状のものが多く，水中で の分散性も良好であり結晶同士のからみ合いあるいは凝 集は認められなかった. $1650^{\circ} \mathrm{C}$ で生成した結晶の化学 組成は, $\mathrm{Al}_{2} \mathrm{O}_{3}: 71.35, \mathrm{SiO}_{2}: 28.31, \mathrm{Fe}_{2} \mathrm{O}_{3}: 0.21$, $\mathrm{TiO}_{2}: 0.03, \mathrm{CaO}:$ Tr., $\mathrm{MgO}:$ Tr., $\mathrm{Na}_{2} \mathrm{O}: 0.08$ $\mathrm{wt} \%, \mathrm{~K}_{2} \mathrm{O}: \mathrm{Tr}$. であり, アルカリ成分の含有が非常に 少ないことが分かった。

\section{2 針状ムライトの高温特性}

ムライトは高融点 $\left(\right.$ 約 $\left.1850^{\circ} \mathrm{C}\right)$ 結晶であり, 熱衝撃 性及びクリープ特性が優れているため, 高温構造材料よ して最近注目されている5) 8).ところで，図10ような 針状ムライトは組成が $3 \mathrm{Al}_{2} \mathrm{O}_{3} \cdot 2 \mathrm{SiO}_{2}$ のムライトに近 い結晶であり，またアスペクト比が 10 ２0であるので セラミックスの強化材として利用できるものと期待され る.しかし，マトリックスのセラミックスと強化材（例

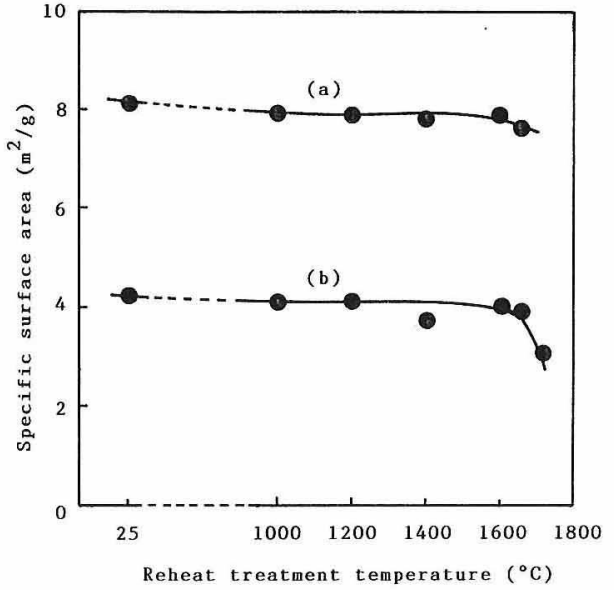

Fig. 2. The change of the specific surface area of needle-like mullite obtained at $1550^{\circ}$ and $1650^{\circ} \mathrm{C}$ by reheat treatment.

(a) $1550^{\circ}$ and (b) $1650^{\circ} \mathrm{C}$

えばウイスカー）の熱膨張率を十分に把握しておかない 之，複合化による補強効果が得られにくい ${ }^{9)}$.

したがって，つぎに針状ムライトの高温下における特 性について検討した。 まず, $1550^{\circ}, 1650^{\circ} \mathrm{C}$ で生成した 針状么ライトを $1000^{\circ} \sim 1720^{\circ} \mathrm{C}$ で 4〜30 時間再加熱し, 比表面積の変化を調べた。結果を図 2 に示す。また図 3 には $1650^{\circ} \mathrm{C}$ で生成した結晶を $1650^{\circ}, 1720^{\circ} \mathrm{C}$ で再加熱 した後の形態を示す. $1550^{\circ}, 1650^{\circ} \mathrm{C}$ 生成物ともに 

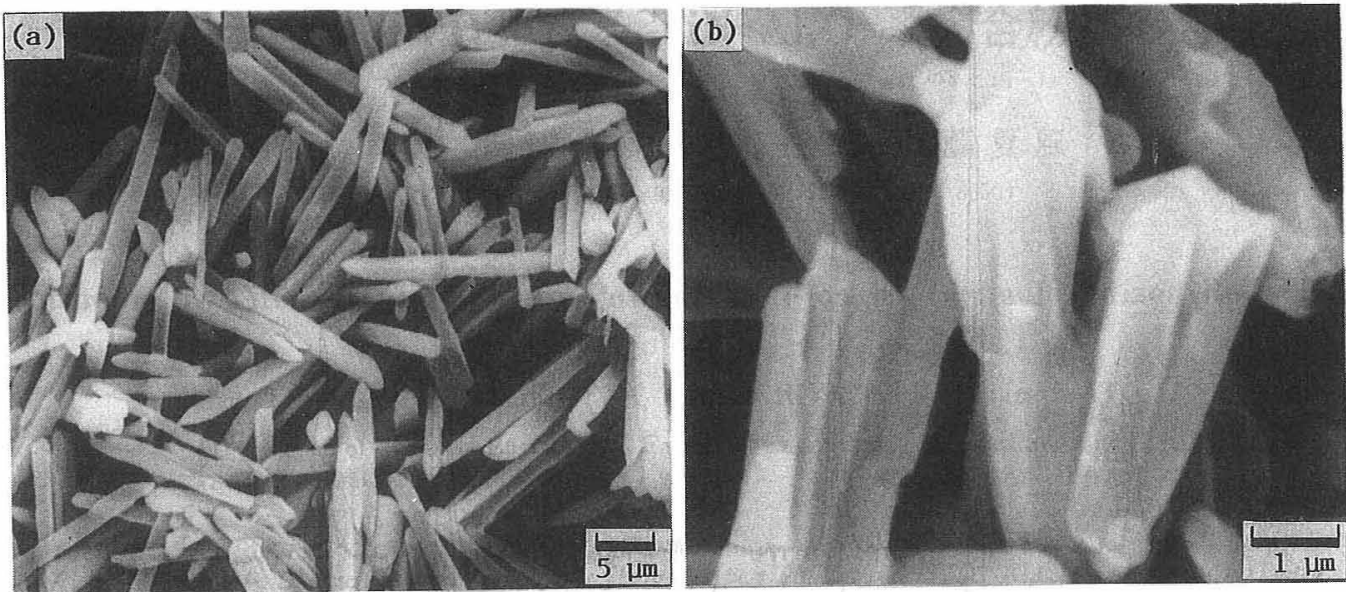

Fig. 3. SEM micrographs of needle-like mullite obtained at $1650^{\circ} \mathrm{C}$ by reheat treatment.

(a) $1650^{\circ} \mathrm{C}$ for $30 \mathrm{~h}$ and (b) $1720^{\circ} \mathrm{C}$ for $4 \mathrm{~h}$

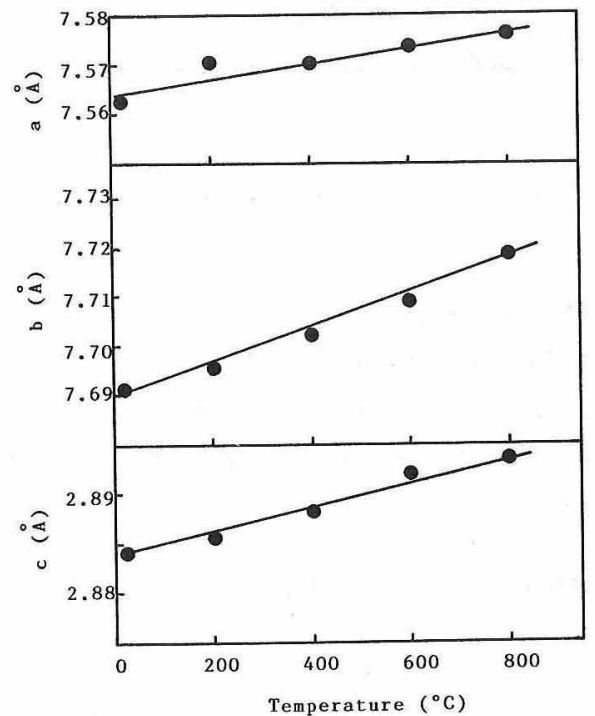

Fig. 4. Lattice constants of needle-like mullite with elevating temperatures measured by a high temperature X-ray diffractometer.

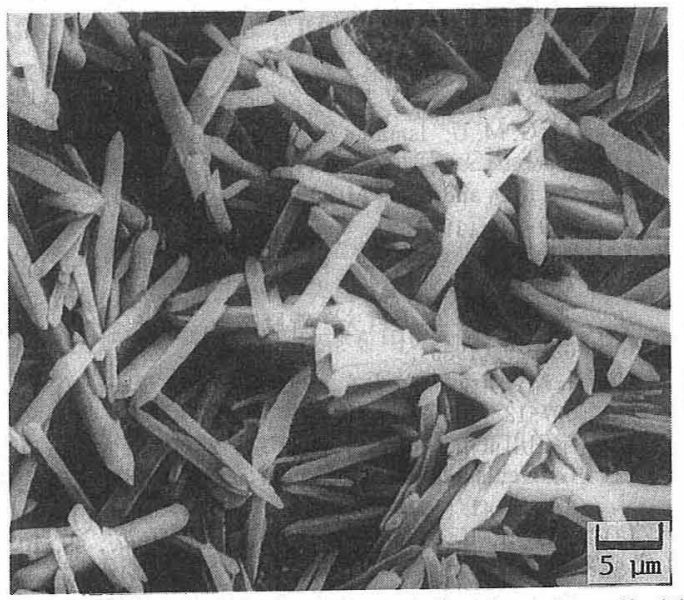

Fig. 5. The morphology of needle-like mullite quenched from $1150^{\circ}$ to $0^{\circ} \mathrm{C}$.

$1650^{\circ} \mathrm{C}$ の再加熱処理では針状ムライトの形状に変化は ほとんど認められず，また比表面積にも変化はなく結晶

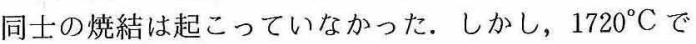
は図 3(b) のように一部の結晶で焼結が始まっており比 表面積は低下した.

以上のように $1720^{\circ} \mathrm{C}$ の再加熱でも針状ムライトはま だ安定であったが,これはこの結晶が $3 \mathrm{Al}_{2} \mathrm{O}_{3} \cdot 2 \mathrm{SiO}_{2}$ の組成のムライトに近いため $1720^{\circ} \mathrm{C}$ では融液相 ${ }^{10)}$ を作 りにくいこと，また一般的にムライトは比較的共有結合 が強いために焼結性にそしくなっている ているものと推察される.

つぎに $1650^{\circ} \mathrm{C}$ で生成した針状ムライトの $25^{\circ} \sim 800^{\circ} \mathrm{C}$ における熱膨張率を調べた結果を図 4 に示す。この結晶 の $a, b, c$ 軸方向の熱膨張係数はそれぞれ $2.2,3.9$, $4.5 \times 10^{-6} /{ }^{\circ} \mathrm{C}$ であり $c$ 軸方向の膨張率が幾分大きいこ とがわかった．宇田川らによるムライト結晶の熱膨張係 数 ${ }^{11)}\left(25^{\circ} \sim 600^{\circ} \mathrm{C}\right)$ はそれぞれ $3.0,5.7,5.0 \times 10^{-6} /{ }^{\circ} \mathrm{C}$, 及び Oehlschlegel ら $\left.{ }^{12}\right)$ にり報告されている值（250

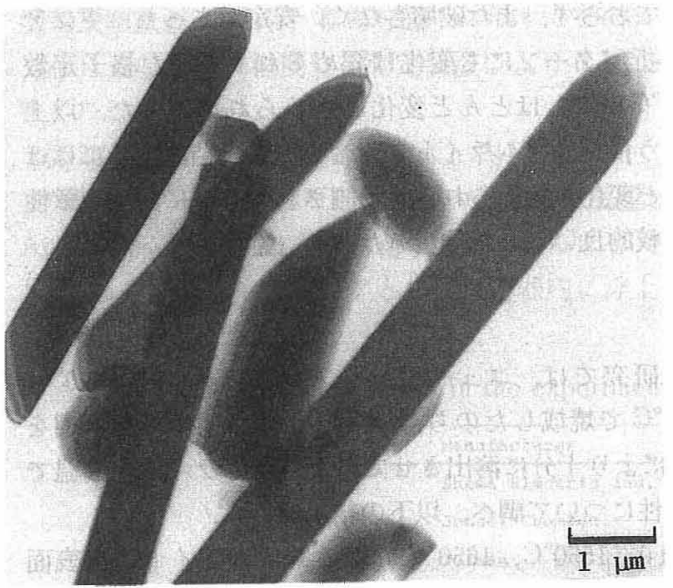

$1 \mu \mathrm{m}$ 


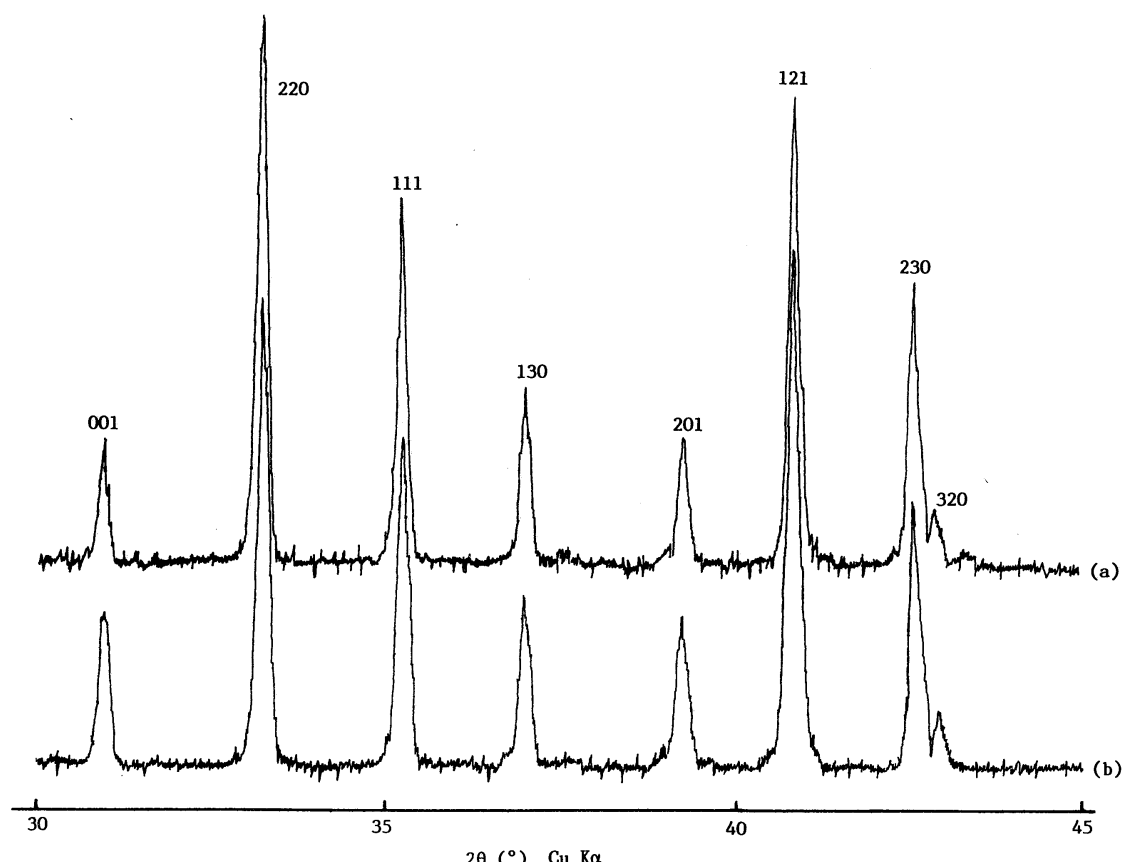

Fig.6. X-ray diffraction patterns of as-grown needle-like mullite and quenched needle-like mullite. (a) as-grown and (b) quenched from $1150^{\circ}$ to $0^{\circ} \mathrm{C}$

$\left.1000^{\circ} \mathrm{C}\right)$ はそれぞれ $4.4,6.6,5.6 \times 10^{-6} /{ }^{\circ} \mathrm{C}$ であるの で，本研究で生成した針状ムライトはより低熱膨張性で あることが分かった。しかし，この相違についてはまだ 明らかでない

ところで一般に低熱膨張性のセラミックスは熱衝撃性 が高いと言われている ${ }^{13) ~ 14)}$. 本研究で得た針状ムライ 卜の平均熱膨張係数は約 $3.5 \times 10^{-6} /{ }^{\circ} \mathrm{C}$ であるのでこの 結晶は比較的低熱膨張性である.したがって，この結晶 の熱衝撃性が興味深いので, 次に $1150^{\circ} \mathrm{C}$ で 2 時間再加 熱したのち急冷し, 形態及び結晶性について調べた. 図 5 に形態を, 図 6 に急冷前後のX線回折図を示す. 図 5 から急冷しても, 針状ムライト中にマイクロクラックは 入っておらず，また破壊もなく，安定であった．更にX 線回折パターンにも変化は認められず, また格子定数 $\left(25^{\circ} \mathrm{C}\right)$ にもほとんど変化は認められなかった. 以上 のように, 針状ムライトを急冷しても, 結晶粒子にはほ とんど変化が認められず，予測されるように耐熱衝撃性 が比較的良いことが分かった。

\section{4. 総 括}

本研究では, ニュージーランドカオリンを $1550^{\circ}$ $1700^{\circ} \mathrm{C}$ で焼成したのち, マトリックス相のガラス相を $\mathrm{HF}$ により十分に溶出させて得た針状ムライトの高温で の特性について調べ, 以下の結果を得た.

（1） $1550^{\circ} \mathrm{C}, 1650^{\circ} \mathrm{C}$ で得た針状ムライトの比表面 積はそれぞれ $8.2,4.1 \mathrm{~m}^{2} / \mathrm{g}$ であったが， $1000^{\circ}$ $1650^{\circ} \mathrm{C}$ で再加熱しても比表面積はほとんど変わらず, また焼結も認められず熱的に安定であった。

(2) $25^{\circ} \sim 800^{\circ} \mathrm{C}$ での熱膨張率は $a, b, c$ 軸それぞ れ $2.2,3.9,4.5 \times 10^{-6} /{ }^{\circ} \mathrm{C}$ であり, 比較的低熱膨張性で あった。

（3） $1150^{\circ} \mathrm{C}$ に加熱したのち $0^{\circ} \mathrm{C}$ へ急冷しても，結 晶は破壊することなく安定であった。

\section{文献}

1）勝木宏昭, 古田祥知子, 一ノ瀬弘道，中尾 浩，セラミッ クス論文誌, 96, 1081-86 (1988).

2) N. L. Bowen and J. W. Greig, J. Am. Ceram. Soc., 7, 238-54 (1924).

3）吉木文平, “鉱物工学”, 技報堂 (1976) pp. 392-94.

4）浜野健也, “窯業の研究 II”, 山内俊吉編, 技報堂 (1961) pp. 301-34.

5）河波利夫, ニューセラミックス, Vol.2, 79-84 (1989).

6) M. G. M. U. Ismail, Z. Nakai and S. Sormiya, J. Am. Ceram. Soc., 70, C 7 (1987).

7) T. Mah and K. S. Mazdiyasni, J. Am. Ceram. Soc., 66, 699-703 (1983).

8）芦塚正博, 奥野 勉, 窪田吉孝, 第 27 回セラミックス基 礎科学討論会講演要旨集 (1989) p. 173.

9）井上茂夫, 内山哲夫, 新原晧一, セラミックス, 21, 621-29 (1986).

10) I. A. Aksay and J.A. Pask, J. Am. Ceram. Soc., 58, 507-12 (1975).

11）宇田川重和, 井上博行, セラミックス, 14, 967-76 (1979).

12) G. Oehlschlegel, A. Kockel and A. Biedl, Glas. Ber. 47, 31-41 (1974).

13) D.P.H. Hasselman, Am. Ceram. Soc. Bull., 49, 1033-37 (1970).

14） 中山 淳, セラミックス, 8, 343-49 (1973). 